\title{
EVALUATION OF TISSUE RESPONSE OF ADULT MALE SPRAGUE-DAWLEY RATS TO AN EXPERIMENTAL CALCIUM SILICATE BASED CEMENT VERSUS ANGELUS WHITE MTA AND SINAI WHITE PORTLAND CEMENT
}

\author{
By \\ Amira Mohammad Samy Mostafa', Mohammad Ali Elyasaky², \\ Maha Ahmad Niazy ${ }^{3}$ and Mohammad Yousry Hassaan ${ }^{4}$

\footnotetext{
${ }^{1}$ Operative Dentistry Department, Faculty of Dentistry Sinai University. and Dean of Faculty of Dentistry Sinai University.

${ }^{4}$ Department of Physics, Faculty of Science Al-Azhar University.
} \\ ${ }^{2}$ Operative Dentistry Department, Faculty of Dental Medicine-(Girls' branch) \\ ${ }^{3}$ Operative Dentistry Department, Faculty of Dental Medicine-(Girls' branch).
}

\begin{abstract}
Background: Calcium silicate cements are biocompatible materials, and can help in repair of osseous defects.

Objective: This study was conducted to evaluate and compare the tissue response to an experimental material (laboratory prepared) versus white MTA and white Portland cement implanted in a rat model.

Materials and methods: The experimental highly purified calcium silicate based material was synthesized denovo in the lab from pure oxides, then tissue response was evaluated on adult Sprague-Dawley rats. Critical size bone defect was done at the middle third of the lateral surface of the right tibia in 75 rats. The bony defect was either left untreated to heal spontaneously in animals of the control group (15 rats) or filled with four different materials ( 15 rats each). At the end of the experimental periods for each subgroup tibia were dissected for histological analysis and evaluation of inflammatory reaction and newly formed bone. Data were collected, tabulated and statistically analyzed. Results: Within the limitations of this study, it was found that there was a decrease in inflammatory cell count as the wound healing process moves towards formation of granulation tissue and fibrous encapsulation of the different implanted materials, as well as deposition of newly formed bone throughout the experimental periods. Conclusion: The synthetic materials (laboratory manufactured) seemed to have comparable biological properties to those of commercially available bioactive materials. These experimental materials have an intense tissue inductive capacity, and also the incorporation of nanotechnology in the experimental material showed an intense biological effect in tissue regeneration.
\end{abstract}

\section{INTRODUCTION}

Calcium silicate based materials are interesting bioceramic products widely used in dentistry. These materials are broadly used in the field of conservative dentistry for regeneration, repair and reconstruction. These are available in different forms and compositions that act directly on vital tissue inducing its healing and repair (Sonarkar and Purba, 2015). Calcium silicate materials derived from 
the basic building material Portland cement were the first bioactive materials to appear for use in dentistry (Jefferies, 2014). Portland cement is a common cement used in civil engineering. The major constituents of ordinary Portland cement are similar to those of MTA. It was reported that their $\mathrm{pH}$, antimicrobial activity, biocompatibility and low resistance to compression are similar (Silva Neto et al., 2011). Mineral trioxide aggregate is a biomaterial that is widely used in various conservative treatments due to its excellent biocompatibility, superior sealing and ability to set in the presence of blood (Suzuki et al., 2015). Many studies compared MTA with Portland cement, and indicated that they have similar chemical composition and biocompatibility. However, MTA is a quite expensive material (Hwang et al., 2009 and Yoshino et al., 2013). Therefore, Portland cement may be a possible substitute for MTA. From the disadvantages of MTA are its long setting time and the presence of bismuth oxide which alter its physicochemical properties. So, zirconium oxide promotes adequate radiopacity and biocompatibility when associated with Portland cement (Tanomaru-Filho et al., 2015). Nanohydroxyapatite (n-HAp) containing products with different formulations have been developed, and early data have suggested their remineralizing properties (Tschoppe et al., 2011).

\section{MATERIALS AND METHODS}

Highly purified calcium silicate based cement was prepared denovo in the physical properties of building materials and refractories lab, department of Physics Faculty of Science, Al-Azhar University, from pure oxides with the same ratio as Sinai white Portland cement by sintering quenching technique and milling procedures. X-ray fluorescence elemental analysis was used to confirm the presence of oxides in the final compound of the calcium silicate prepared powder. Phase composition and microstructure were then characterized with an X-ray diffractometer (XRD) by placing the powder specimen into the sample holder for detection. To prepare the experimental material, 20 weight percent radiopacifing materials (10 weight percent zirconium oxide powder (Malkondu et al., 2014), and 10 weight percent titanium oxide powder (Hossienzade et al., 2016) were added to 80 weight percent experimental calcium silicate powder. Other group (Experimental material + nHAp) was prepared by adding 10 weight percent hydroxyapatite nanoparticles to a sample from the previously prepared experimental material (Guerreiro-Tanomaru et al., 2016). To prepare aqueous solution of calcium chloride, ten percent calcium chloride powder was added to distilled water (Camilleri et al., 2013) to decrease the setting time of the cement.

Sample grouping and surgical procedures:

Approval for the animal use protocol was sought and given by the Animal Ethics Committee at Faculty of Dentistry, Al Azhar University Girls' branch. A total 


\section{EVALUATION OF TISSUE RESPONSE OF ADULT MALE SPRAGUE-DAWLEY... ${ }^{3}$}

of 75 adult male rats each weighing from 300 to $350 \mathrm{~g}$ were used in this work. They were kept in cages $(30 \times 25 \times 25) \mathrm{cm}$ dimensions (2 rats per cage) at room temperature and normal dark/light cycle. They were fed on chow pellets and water ad lib. They were divided equally into 5 main groups according to the surgical procedure and the type of material used (A) Sinai white Portland cement (A1), Angelus white MTA (A2), experimental material (A3) and experimental material with hydroxyapatite nanoparticles (A4) and a control group (only critical size bone defect) (A0). Each group was further subdivided into 3 subgroups of 5 rats each according to the time interval of sacrification (B).Subgroup I: Rats were sacrificed 1 day post operatively B1 (Rammelt et al., 2004), Subgroup II: Rats were sacrificed 1 week post operatively B2 (Dincol et al., 2016) and Subgroup III: Rats were sacrificed 1 month post operatively B3 (Dincol et al., 2016).

After one week of acclimation, rats of different groups were anesthetized by intraperitoneal injection of Ketamine Hydrochloride $10 \%^{1} \quad(35 \mathrm{mg} / \mathrm{kg}$ body weight) and Xylazine Hydrochloride $2 \%^{2}$ ( $8 \mathrm{mg} \backslash \mathrm{kg}$ body weight) (Silva et al., 2015). All operative procedures were done under strict aseptic conditions and every effort was made to minimize animal discomfort. The surgical site (right tibia) was then shaved with One cream $^{3}$ and

\footnotetext{
${ }^{1}$ Sigma-Tec Pharmaceutical industries-Egypt

${ }^{2}$ ADWIA Company-Egypt

${ }^{3}$ Eva Cosmetics company-Egypt
}

disinfected with Betadine solution ${ }^{4}$, and a linear $15 \mathrm{~mm}$ incision was made on the tibia and a full thickness skin muscle periosteal flaps were reflected. The anterior tibial muscle was retracted laterally in order to expose the tibial bone. A $4 \mathrm{~mm}$ bone defect (fig. 1) which is considered a surgical critical-size bone hole (Bernabe et al., 2012) was done at the middle third of the lateral surface of the right tibia (Nygern et al., 2014) using a sterile carbide dental round bur ${ }^{5}$ size 1/4 ( $4 \mathrm{~mm}$ checked by periodontal probe) on a low speed hand piece ${ }^{6}$ with 25000 r.p.m under constant saline irrigation ${ }^{7}$ as a coolant. After performance of the surgical procedures the bony defect was either left untreated to heal spontaneously in animals of the control group or filled with different materials according to the different groups. After that the periosteum and muscles were repositioned properly over the defect and sutured with (2/0) catgut resorbable suture ${ }^{8}$ then the skin was repositioned properly and sutured with (3/0) silk suture ${ }^{9}$. Following the surgery the animals were allowed to resume normal activity immediately after surgery. Each rat received intramascular injection of Cephotaxime $1000 \mathrm{mg}^{10}$ (third generation of cephalosporin antibiotics), and post-surgical pain was treated with

4 The Nile company for Pharmaceuticals and Chemical Industries-Egypt

${ }^{5}$ ELA Carbide-Germany

${ }^{6}$ Olympia-Japan

${ }^{7}$ Egypt Otsuka Pharmaceutical Company

${ }^{8}$ International sutures manufacturing Co. Egypt

${ }^{9}$ KeeboMed- USA

${ }^{10}$ Advocure Pharmaceuticals-Egypt 


\section{AMIRA MOHAMMAD SAMY MOSTAFA et al.}

subcutaneous injection of Ketoprufen $75 \mathrm{mg} \backslash \mathrm{ml}^{11}$ (antinflamatory and analgesic) 3 days postoperatively. Dose was calculated according to animal ethics committee pain control protocol. The animals were observed daily by the veteranian for any adverse effects related to the surgery. At the end of the experimental period, each subgroup rats was sacrificed by over dose of anesthesia. Tibiae were dissected free from any soft tissue carefully and the defect zone were defined as the area of interest.

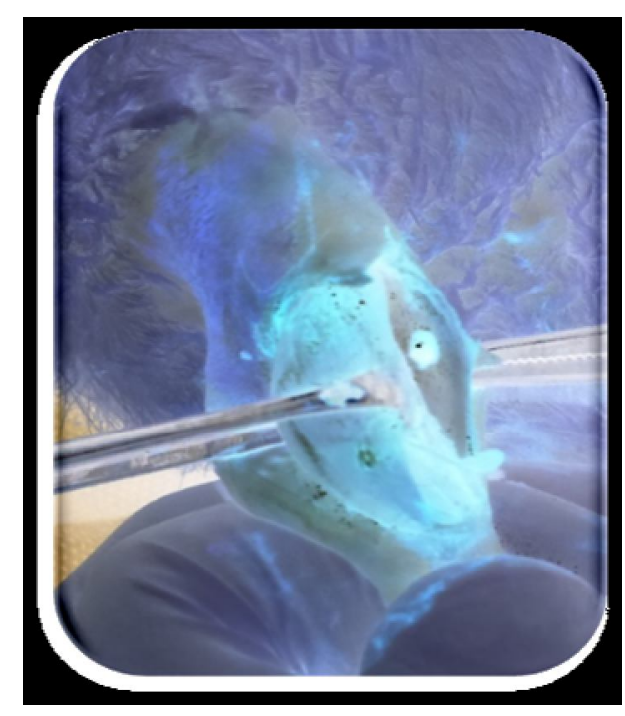

Fig. (1): Critical size bone defect

After sacrificing the animals, their tibiae were dissected and prepared for Paraffin sections. Finally, the sections were stained by hematoxyline and eosin stain (H\&E) for routine histological examination under light microscope and Masson Trichrome special stain (MT) to detect areas of new collagen formation. Slides were digitized using Canon digital camera $^{12}$ mounted on Leica light

\footnotetext{
${ }^{11}$ Amriya Pharm Ind.-Egypt

12 Power shot S70- Japan
}

microscope ${ }^{13}$ using 40X objective lens for (H\&E) slides (Silva et al., 2015) and 20X objective lens for (MT) slides (Saghiri et al., 2015). Images were then transferred to the computer system for detection of inflammatory reaction and the bone density analysis were carried out using Image J, 1.41a (NIH, USA) image analysis software. For inflammatory cell count to standardize the results, 5 fields for each section were taken at magnification 400X. For bone area fraction, 5 fields at magnification $200 \mathrm{X}$ were obtained for each section. Data were collected and tabulated for statistical analysis.

Statistical analysis was performed using IBM ${ }^{\circledR}$ SPSS ${ }^{\circledR}$ Statistics Version 20 for Windows. One-way ANOVA followed by Tukey post hoc-test which was used to compare between more than two groups in non-related samples. Repeated measure ANOVA and paired sample t-test were used to compare between related samples in two (Paired sample t-test) and more (ANOVA) groups. The significance level was set at $\mathrm{P} \leq 0.05$.

\section{RESULTS}

\section{I- Inflammatory cell count:}

\section{Relation between different study groups} and each period of implantation (Table 1):

After 1 day of sacrificing (Figures: 2ae): The highest mean value was found in Control group $(172.00 \pm 11.22)$ while the least mean value was found in (Experimental material $+\mathrm{CaCl}_{2}$ solution) $(155.00 \pm 5.20)$ group. No statistically

\footnotetext{
${ }^{13}$ Germany
} 


\section{EVALUATION OF TISSUE RESPONSE OF ADULT MALE SPRAGUE-DAWLEY...}

significant difference was found between Control, Sinai white Portland cement, Angelus white MTA, (Experimental material $+\mathrm{CaCl}_{2}$ solution) and (Experimental material $+\mathrm{nHAp}+\mathrm{CaCl}_{2}$ solution) where $(\mathrm{p}=0.110)$.

\section{After 1 week of sacrificing (Figures: 3} a-e): The highest mean value was found in Control (196.20 \pm 19.31$)$ while the least mean value was found in (Experimental material $+\mathrm{nHAp}+\mathrm{CaCl}_{2}$ solution) $(163.20 \pm 5.12)$ group. A statistically significant difference was found between Control, Sinai white Portland cement, Angelus white MTA, (Experimental material $+\mathrm{CaCl}_{2}$ solution and (Experimental material $+\mathrm{nHAp}+\mathrm{CaCl}_{2}$ solution) groups where $(\mathrm{p}<0.001)$.

After 1 month of sacrificing (Figures: 4 a-e): The highest mean value was found in Control $(159.20 \pm 11.01)$ group while the least mean value was found in (Experimental material $+\mathrm{nHAp}+\mathrm{CaCl}_{2}$ solution) $(92.00 \pm 15.68)$. A statistically significant difference was found between Control, Sinai white Portland cement, Angelus white MTA, (Experimental material $+\mathrm{CaCl}_{2}$ solution and (Experimental material $+\mathrm{nHAp}+\mathrm{CaCl}_{2}$ solution) where $(\mathrm{p}<0.001)$.

Table (1): Inflammatory cell count of different study groups.

\begin{tabular}{|c|c|c|c|c|c|c|c|}
\hline \multirow[b]{2}{*}{ Variables } & \multicolumn{2}{|c|}{ After 1 day } & \multicolumn{2}{|c|}{ After 1 week } & \multicolumn{2}{|c|}{ After 1 month } & \multirow[b]{2}{*}{$P$-value } \\
\hline & Mean & SD & Mean & SD & Mean & SD & \\
\hline Control & $172.00^{\mathrm{aA}}$ & 11.22 & $196.20^{\mathrm{abB}}$ & 19.31 & $159.20^{\mathrm{aC}}$ & 11.01 & $0.001 *$ \\
\hline Sinai white Portland cement & $170.40^{\mathrm{aA}}$ & 11.41 & $190.80^{\mathrm{abB}}$ & 7.56 & $157.80^{\mathrm{aC}}$ & 13.07 & $0.001 *$ \\
\hline Angelus white MTA & $168.20^{\mathrm{aA}}$ & 8.29 & $179.60^{\mathrm{bcB}}$ & 6.19 & $116.60^{\mathrm{bC}}$ & 11.39 & $<0.001 *$ \\
\hline $\begin{array}{l}\text { Experimental material + } \\
\mathrm{CaCl}_{2} \text { solution }\end{array}$ & $155.00^{\mathrm{aA}}$ & 5.20 & $166.60^{\mathrm{cB}}$ & 7.09 & $110.20^{\mathrm{bcC}}$ & 9.78 & $<0.001 *$ \\
\hline $\begin{array}{l}\text { Experimental material +nHAp } \\
\quad+\mathrm{CaCl}_{2} \text { solution }\end{array}$ & $155.20^{\mathrm{aA}}$ & 7.43 & $163.20^{\mathrm{cB}}$ & 5.12 & $92.00^{\mathrm{cC}}$ & 15.68 & $<0.001 *$ \\
\hline P-value & \multicolumn{2}{|c|}{0.110} & \multicolumn{2}{|c|}{$<0.001 *$} & \multicolumn{2}{|c|}{$<0.001 *$} & \\
\hline
\end{tabular}

Mean values with different lower-case subscripts in the same column indicate statistically significance difference, mean values with different upper-case subscripts in the same row indicate statistically significance difference. *; significant 


\section{AMIRA MOHAMMAD SAMY MOSTAFA et al.}

\section{Haematoxyline and Eosin stain (H\&E - 400X sections):}

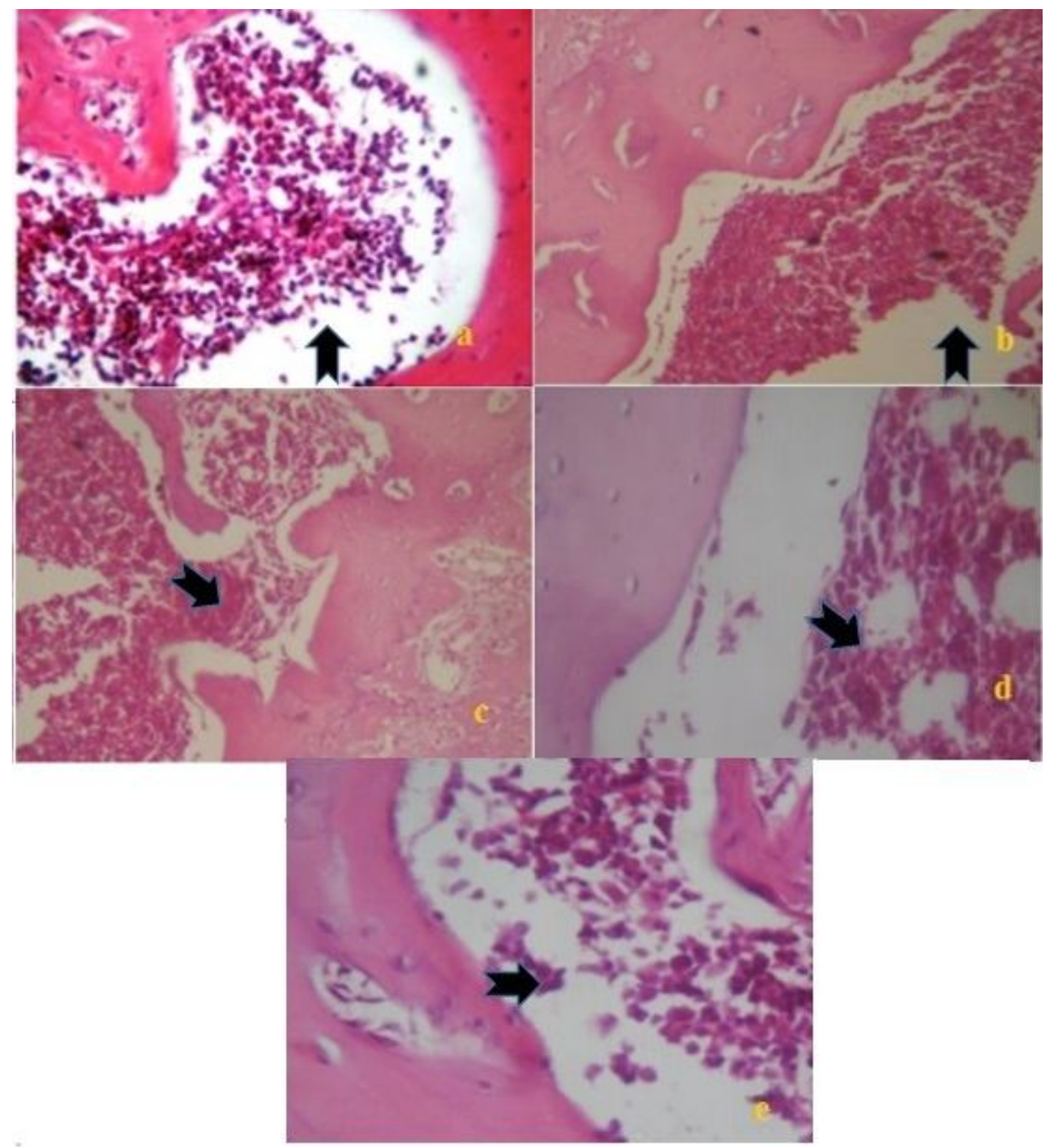

Figure (2 a-e): Photomicrograph after 1 day of sacrificing from different study groups showing the area of bone defect with extensive chronic and acute inflammatory reaction (black arrows).

a- Control group (172 \pm 11.22$)$

b- Sinai white Portland cement $(170.40 \pm 11.41)$

c- Angelus white MTA (168.20 \pm 8.29$)$

d- Experimental material $+\mathrm{CaCl}_{2}$ solution $(155.00 \pm 5.20)$

e- Experimental material $+\mathrm{nHAp}+\mathrm{CaCl}_{2}$ solution $(155.20 \pm 7.43)$ 
EVALUATION OF TISSUE RESPONSE OF ADULT MALE SPRAGUE-DAWLEY... 7

\section{Haematoxyline and Eosin stain (H\&E - 400X sections):}

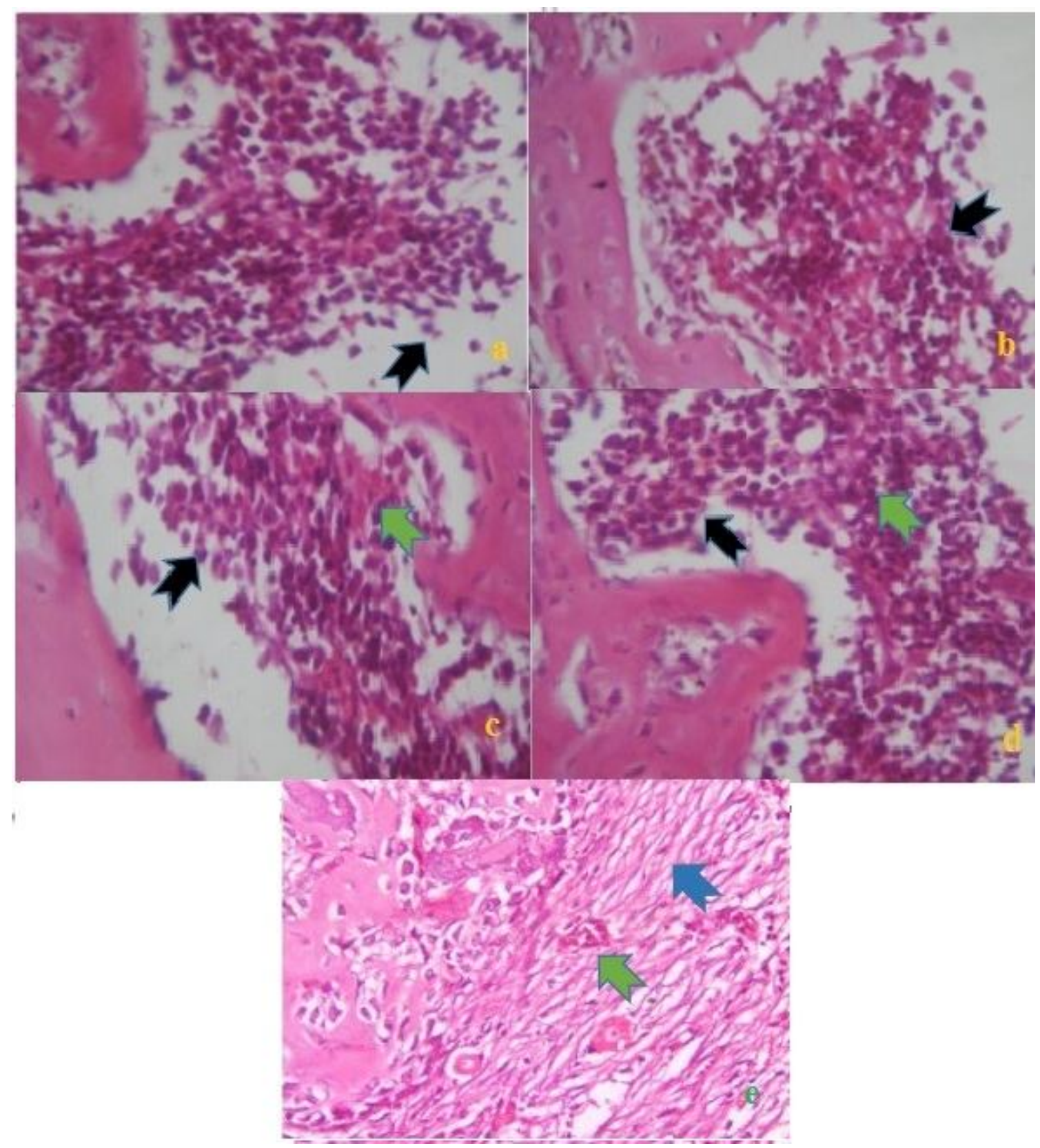

Figure (3 a-e): Photomicrograph after 1 week of sacrificing from different study groups showing the area of bone defect with extensive chronic inflammatory cells (black arrows), small foci of immature osteoid tissue matrix appear in groups (c\&d) (green arrows) and immature osteoid tissue with dense and coarse collagen bundles in group (e) (blue arrow). a- Control group (196.20 \pm 19.31$)$

b- Sinai white Portland cement group $(190.80 \pm 7.56)$

c- Angelus white MTA group $(179.60 \pm 6.19)$

d- Experimental material $+\mathrm{CaCl}_{2}$ solution $(166.60 \pm 7.09)$

e- Experimental material $+\mathrm{nHAp}+\mathrm{CaCl}_{2}$ solution $(163.20 \pm 5.12)$ 


\section{Haematoxyline and Eosin stain (H\&E - 400X sections):}

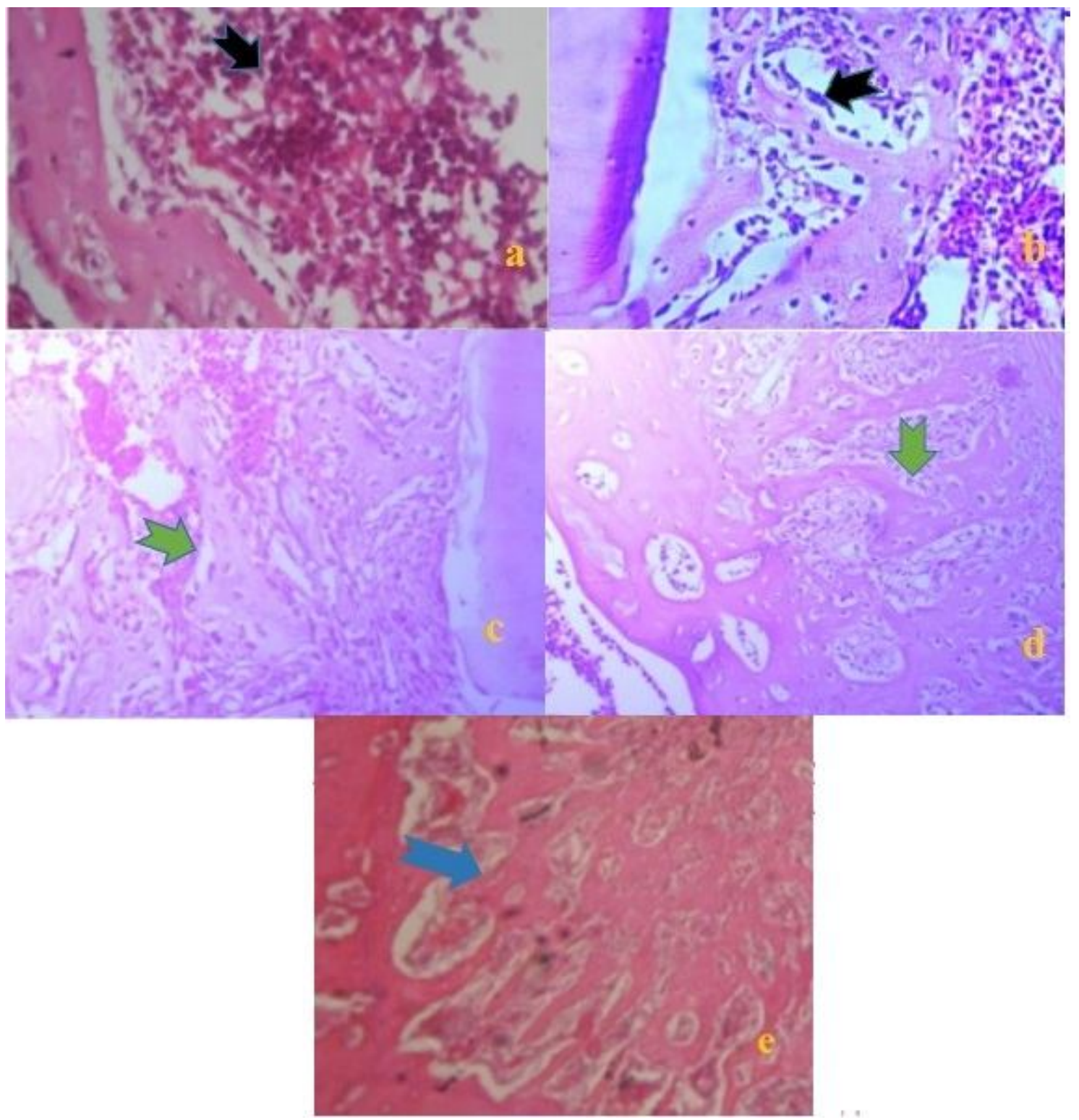

Figure (4a-e): Photomicrograph after 1 month of sacrificing from different study groups showing the area of bone defect with small foci of calcification admixed with moderate chronic inflammatory cells in groups (a\&b) (black arrows), well-formed bone trabeculae in groups (c\&d) (green arrows) and reparative mature osteoid tissue in group (e) (blue arrow). a- Control group (159.20 \pm 11.01$)$

b- Sinai white Portland cement group $(157.80 \pm 13.07)$

c- Angelus white MTA group (116.60 \pm 11.39$)$

d- Experimental material $+\mathrm{CaCl}_{2}$ solution $(110.20 \pm 9.78)$

e- Experimental material $+\mathrm{nHAp}+\mathrm{CaCl}_{2}$ solution $(92 \pm 15.68)$ 
EVALUATION OF TISSUE RESPONSE OF ADULT MALE SPRAGUE-DAWLEY...

\section{II- New bone formation:}

Relation between groups in each time period (Table 2):

After 1 day of sacrificing Figures (5 ae):_The highest mean value was found in (Experimental material $+\mathrm{nHAp}+\mathrm{CaCl}_{2}$ solution $)(0.10 \pm 0.02)$ while the least mean value was found in Control group $(0.00 \pm 0.00)$. A statistically significant difference was found between Control, Sinai white Portland cement, Angelus white MTA, (Experimental material + $\mathrm{CaCl}_{2}$ solution) and (Experimental material $+\mathrm{nHAp}+\mathrm{CaCl}_{2}$ solution) where $(\mathrm{p}<0.001)$.

After 1 week of sacrificing Figures (6 ae): The highest mean value was found in (Experimental material $+\mathrm{nHAp}+\mathrm{CaCl}_{2}$ solution) group $(1.78 \pm 0.18)$ while the least mean value was found in Control
$(0.03 \pm 0.01)$. A statistically significant difference was found between Control, Sinai white Portland cement, Angelus white MTA, (Experimental material + $\mathrm{CaCl}_{2}$ solution) and (Experimental material $+\mathrm{nHAp}+\mathrm{CaCl}_{2}$ solution) where $(\mathrm{p}<0.001)$.

After 1 month of sacrificing Figures (7 a-e): The highest mean value was found in (Experimental material $+\mathrm{nHAp}+$ $\mathrm{CaCl}_{2}$ solution) group $(3.14 \pm 0.15)$ while the least mean value was found in Control $(0.11 \pm 0.05)$. A statistically significant difference was found between Control, Sinai white Portland cement, Angelus white MTA, (Experimental material + $\mathrm{CaCl}_{2}$ solution) and (Experimental material $+\mathrm{nHAp}+\mathrm{CaCl}_{2}$ solution) where $(\mathrm{p}<0.001)$.

Table (2): Newly formed bone of different study groups:

\begin{tabular}{|c|c|c|c|c|c|c|c|}
\hline \multirow{2}{*}{ Groups $\begin{array}{c}\text { New bone } \\
\text { formation }\end{array}$} & \multicolumn{2}{|c|}{ After 1 day } & \multicolumn{2}{|c|}{ After 1 week } & \multicolumn{2}{|c|}{ After 1 month } & \multirow[b]{2}{*}{ P-value } \\
\hline & Mean & SD & Mean & SD & Mean & SD & \\
\hline Control & $\begin{array}{l}0.000 \\
\mathrm{dC}\end{array}$ & 0.000 & $\begin{array}{l}0.032 \\
\mathrm{cB}\end{array}$ & 0.015 & $\begin{array}{l}0.110 \\
\mathrm{dA}\end{array}$ & 0.045 & $0.017 *$ \\
\hline $\begin{array}{l}\text { Sinai white Portland } \\
\text { cement }\end{array}$ & $\underset{\mathrm{cB}}{0.030}$ & 0.023 & $\begin{array}{l}0.102^{\mathrm{bc}} \\
\mathrm{A}\end{array}$ & 0.013 & ${ }_{\mathrm{dA}}^{0.138}$ & 0.036 & $0.006^{*}$ \\
\hline Angelus white MTA & $\begin{array}{l}0.054 \\
\text { bcc }\end{array}$ & 0.011 & $\begin{array}{l}0.184^{\text {bc }} \\
\text { ( }\end{array}$ & 0.011 & ${ }_{\mathrm{cA}}^{1.318}$ & 0.250 & $<0.001 *$ \\
\hline $\begin{array}{l}\text { Experimental material + } \\
\mathrm{CaCl}_{2} \text { solution }\end{array}$ & $\begin{array}{l}0.072 \\
\text { abC }\end{array}$ & 0.008 & $\begin{array}{l}0.228 \\
b B\end{array}$ & 0.059 & ${ }_{\mathrm{bA}}^{1.988}$ & 0.201 & $<0.001 *$ \\
\hline $\begin{array}{l}\text { Experimental material + } \\
\text { nHAp }+\mathrm{CaCl}_{2} \text { solution }\end{array}$ & $\begin{array}{l}0.098 \\
\mathrm{aC}\end{array}$ & 0.015 & ${ }_{\mathrm{aB}}^{1.776}$ & 0.176 & ${ }_{\mathrm{aA}}^{3.142}$ & 0.145 & $<0.001 *$ \\
\hline P-value & \multicolumn{2}{|c|}{$<0.001 *$} & \multicolumn{2}{|c|}{$<0.001 *$} & \multicolumn{2}{|c|}{$<0.001 *$} & \\
\hline
\end{tabular}

Mean values with different lower-case subscripts in the same column indicate statistically significance difference, mean values with different upper-case subscripts in the same row indicate statistically significance difference. *; significant 


\section{Masson Trichrome stain (MT - 200X sections):}

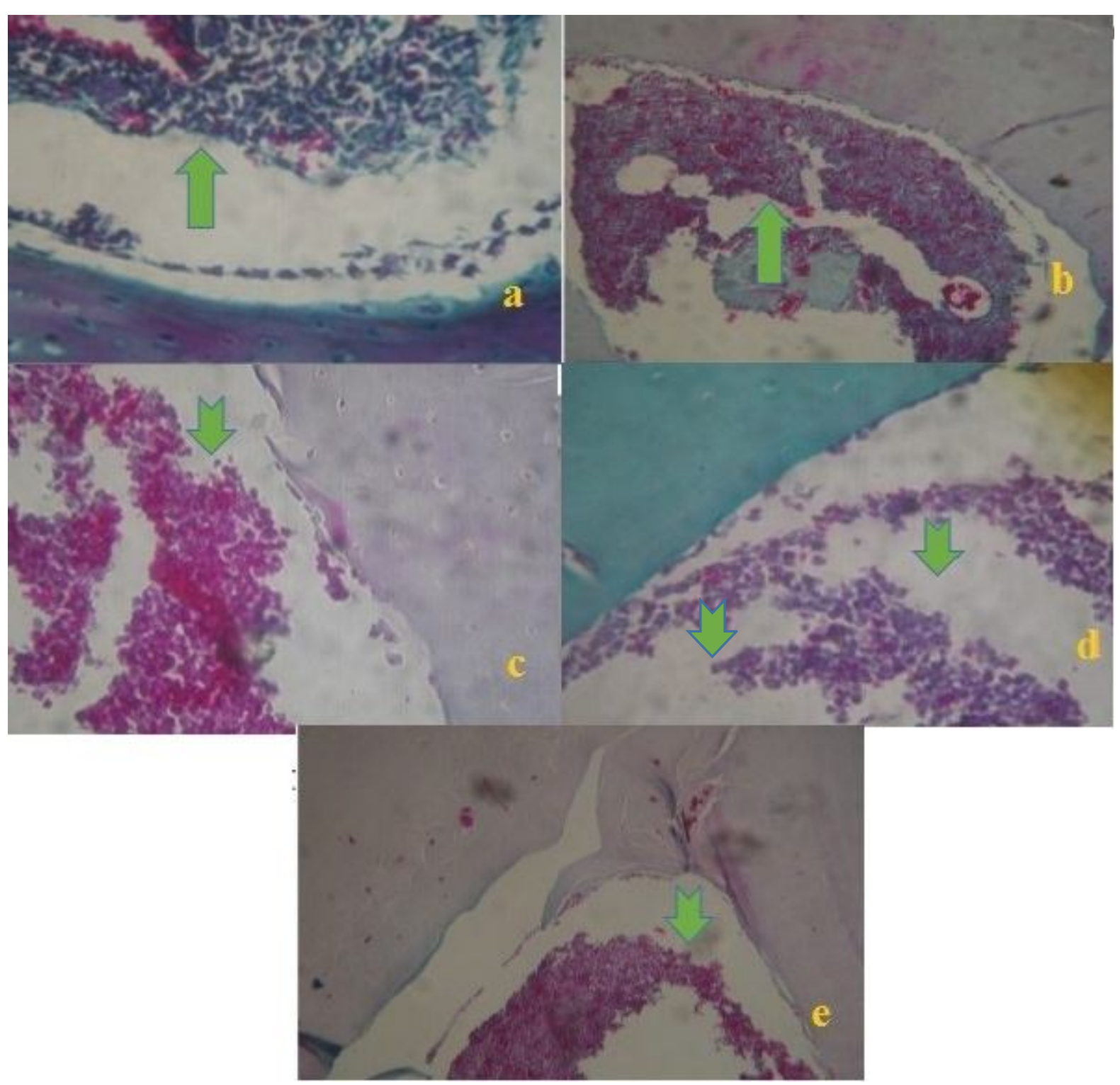

Figure (5 a-e): Photomicrograph after 1 day of sacrificing from different study groups showing the area of bone defect with intense inflammatory cells infiltrate in all groups (green arrows)

a- Control group

b- Sinai white Portland cement group

c- Angelus white MTA group

d- Experimental material $+\mathrm{CaCl}_{2}$ solution

e- Experimental material $+\mathrm{nHAp}+\mathrm{CaCl}_{2}$ solution 
EVALUATION OF TISSUE RESPONSE OF ADULT MALE SPRAGUE-DAWLEY... 11

Masson Trichrome stain (MT - 200X sections):

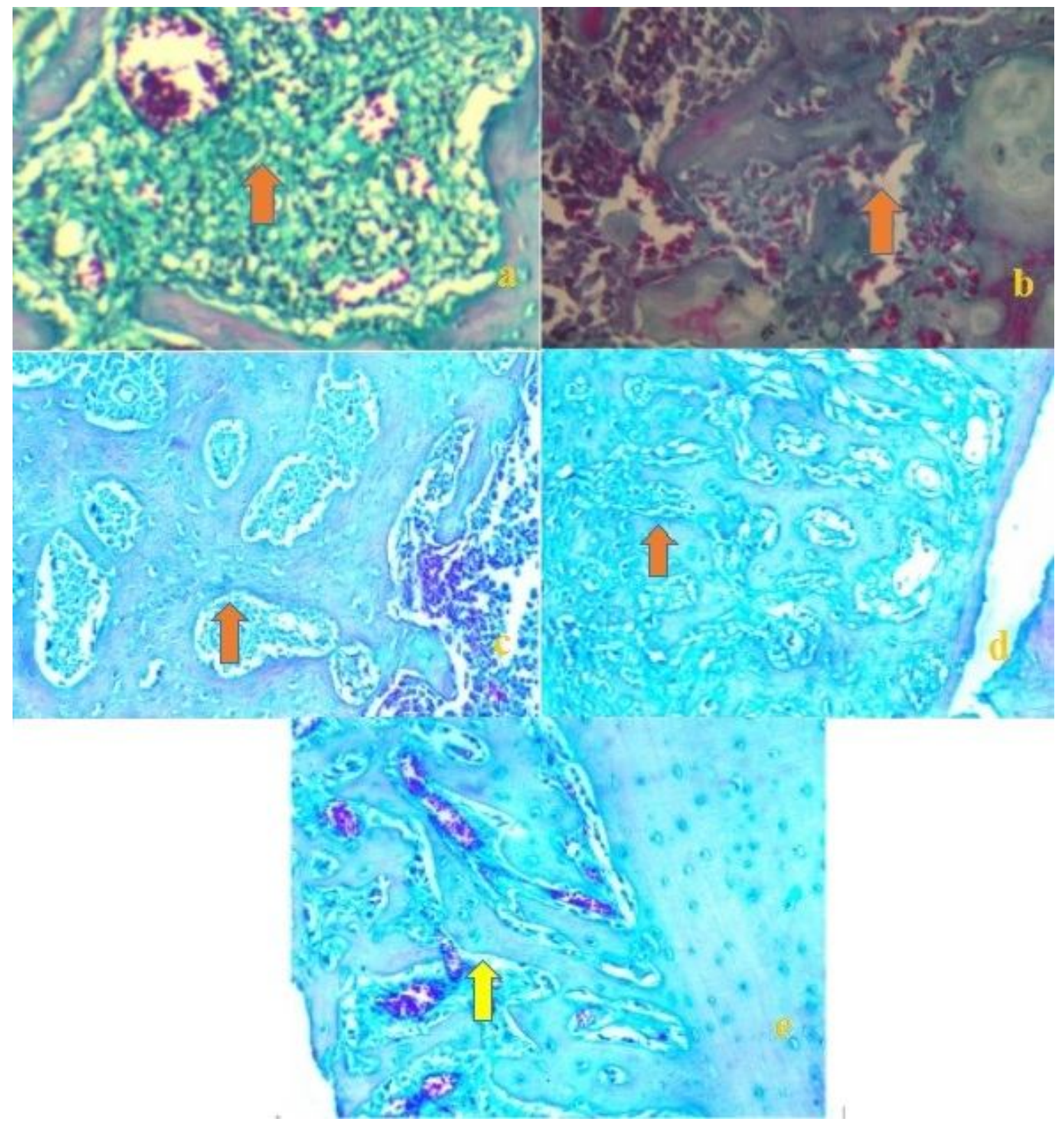

Figure (6 a-e): Photomicrograph after 1 week of sacrificing from different study groups showing the area of bone defect filled with a mass of granulation tissue in all groups (orange arrows) and marked collagen fibers around the newly formed immature bony matrix in group (e) (yellow arrow)

a- Control group

b- Sinai white Portland cement group

c- Angelus white MTA group

d- Experimental material $+\mathrm{CaCl}_{2}$ solution

e- Experimental material $+\mathrm{nHAp}+\mathrm{CaCl}_{2}$ solution 


\section{Masson Trichrome stain (MT - 200X sections):}

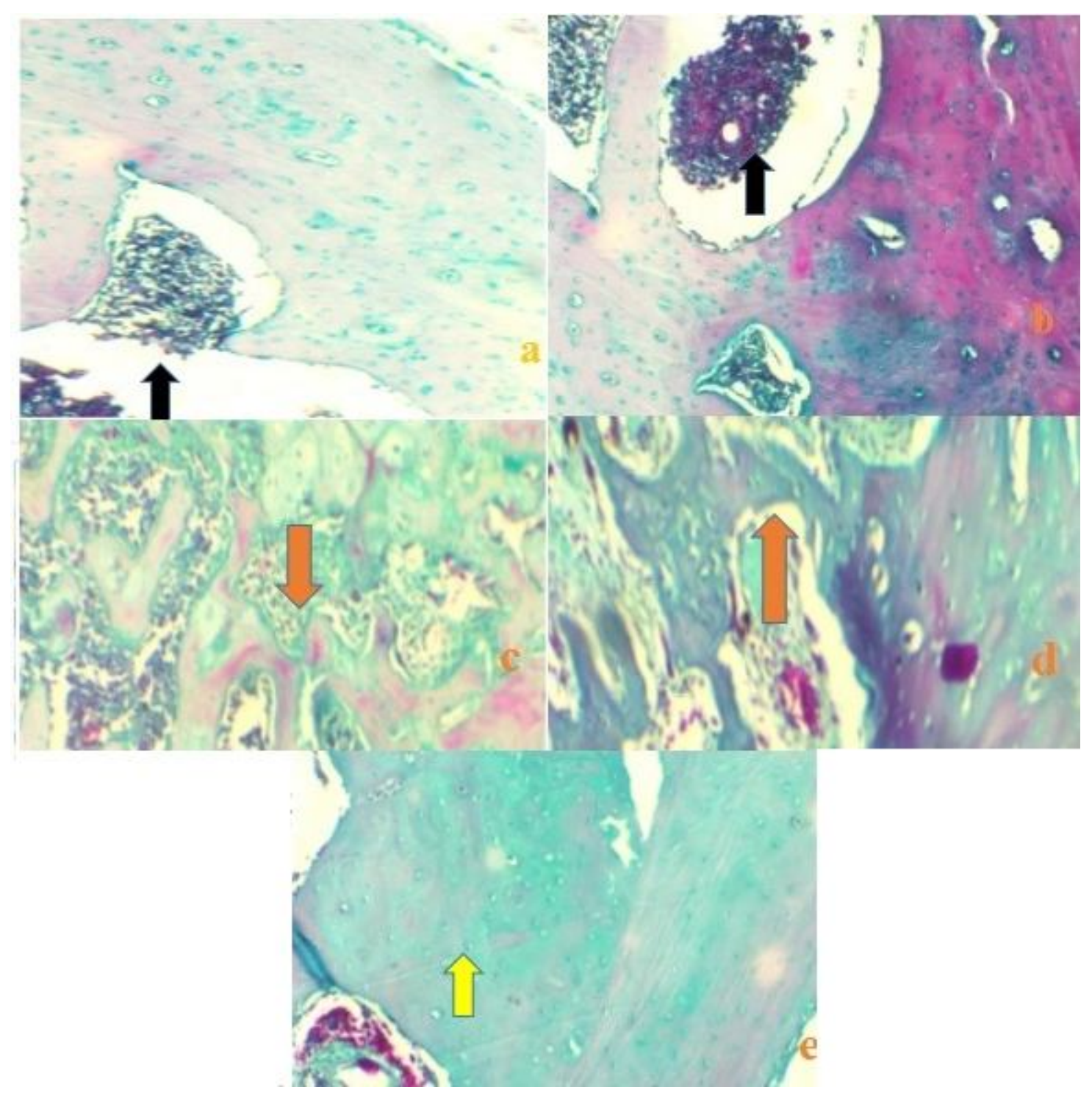

Figure (7 a-e): Photomicrograph after 1 month of sacrificing from different study groups showing the area of bone defect filled with persistent chronic inflammation in groups (a\&b) (black arrows), bony spicules enlarged maturated and coalesced with each other in groups (c\&d) (orange arrows) and increased amount and organization of bone mass with marked maturity in group (e) (yellow arrow).

a- Control group

b- Sinai white Portland cement group

c- Angelus white MTA group

d- Experimental material $+\mathrm{CaCl}_{2}$ solution

e- Experimental material $+\mathrm{nHAp}+\mathrm{CaCl}_{2}$ solution 


\section{EVALUATION OF TISSUE RESPONSE OF ADULT MALE SPRAGUE-DAWLEY... ${ }^{13}$}

\section{DISCUSSION}

For microscopic evaluation of biocompatibility of dental materials, Federation Dentaire International (FDI) recommends inflammatory cell count in different areas of microscopic sections (Vosoughhosseini et al., 2012).

Monitoring of a specific response to the foreign body following the material implantation starts with inflammation continuing through the stages of wound healing with the involvement of various cell types specific for tissue repair, through which the total number of inflammatory cells decrease while the wound healing process moves towards formation of granulation tissue and fibrous encapsulation of the implanted material (Opacic-Galic et al., 2017).

Formation of calcium hydroxide is the cause of high alkalinity of MTA after hydration, which is considered an initial tissue irritant when MTA cement comes into contact with the tissue that provokes severe inflammatory reaction which subsides by time (Saghiri et al., 2013). The lower inflammatory reaction in MTA Angelus group compared to Portland cement group in different implantation periods could be related to the presence of some impurities and other heavy metals in non-dental cements (Minotti et al., 2015), but Portland cement exhibited other properties similar to MTA such as antiinflammatory effect, and this could be the reason of decreased inflammatory reaction in Sinai white Portland cement group than the control group in this study as Portland cement has an inhibitory effect on prostaglandins (Tenorio de France et al., 2010)

An experimental bone wound used to asses repair should be large enough to preclude spontaneous healing. Also, for achieving successful repair and regeneration in the clinical treatment of critical-sized bone defects, the material should satisfy the following desirable criteria, ability to maintain in vivo mechanical stability at the defect site and withstand physiological loads, radiopacity for easy implant monitoring using noninvasive methods such as X-ray and micro-computed tomography $(\mu-\mathrm{CT})$. Bioactivity to promote integration with host bone, ability to degrade at a controlled rate that matches the rate of new bone formation and ability to allow easy handling and sterilization (No et al., 2017).

The results of this study showed that all the tested cements are bioactive as they induced mineral deposition with differences in speed and intensity of deposition. This could be attributed to the calcium ions released from the tested cements that react with phosphate ions in the tissue fluid, resulting in the precipitation of carbonated apatite which is important to the formation and maintenance of the bone biomaterial interface (Dreger et al., 2012).

In all study groups, an increase of osteoid tissue from the period of one week up to one month was observed, the best results in terms of area of more osteoid tissue formed was in group (Experimental material $+\mathrm{nHAp}+\mathrm{CaCl}_{2}$ solution) after one month of implantation, that could be 
related to the nano-hydroxyapatite which improve bone mineralization due to its chemical similarity to the mineral component of bone.

It was reported that the high level of calcium and phosphorus deposition when the calcium silicate based cements were associated with $\mathrm{ZrO}_{2}$ nanoparticles indicates the formation of a layer of hydroxyapatite on the surface of the powder when comes in contact with phosphate buffered solution, thus reinforcing its bioactive potential (BossoMartelo et al., 2017).

Moreover, calcium fluoride $\left(\mathrm{CaF}_{2}\right)$ was found to have a synergistic effect on apatite forming ability of calcium silicate cements (Gandolfi et al., 2011). This is in agreement with the results of this study as the experimental material contained (0.3 weight percent) calcium fluoride that gave a more reactive osteoid tissue formation than the other two tested commercial materials.

Calcium sulphate, typically in the form of dihydrate (Gypsum) are widely recognized as safe and bioactive implant materials that have been successfully used as bone substitutes. Once it reacts with water, it creates a resorbable phase and the reaction results in the growth of interlocking needle like crystals that form the set cement. Also it is used as a drug delivery material (Saghiri et al., 2015).

In MTA Angelus group, deposition of newly formed bone throughout the experimental periods may be due to the presence of silicon oxide $(\mathrm{SiO} 2)$ in the cement which acts as a suitable bed for apatite precipitation (Hosseinzade et al.,
2016). The deposition of hard tissue on implantation of MTA Angelus could be related to its biocompatibility, alkaline $\mathrm{pH}$, the presence of calcium and phosphate ions in its formulation and stimulation of expression of alkaline phosphatase by fibroblasts (Silva et al., 2015).

\section{CONCLUSION}

According to histological responses observed in this study that (Experimental material $+\mathrm{nHAp}+\mathrm{CaCl}_{2}$ solution) is a reliable material in bone defects which are of major concern in the restorative field.

\section{REFERENCES}

1. Bernabe P, Cintra L, Gomes-Filho J, Jr E (2012): Bone healing in critical size defects treated with either bone graft, membrane, or a combination of both materials: a histological and histometric study in rat tibiae. Clin Oral Impl Res., 23:384-8.

2. Bosso-Martelo R, Guerreiro-Tanomaru JM, Viapiana R, Berbert FL, Bernardi MI and Tanomaru-Filho M (2015): Calcium silicatebased cements associated with micro- and nanoparticle radiopacifiers: physicochemical properties and bioactivity. International scholarly research notices, 1-7.

3. Camilleri J, Sorrentino $F$ and Damidot (2013): Investigation of the hydration and bioactivity of radiopacified tricalcium silicate cement, Biodentine and MTA Angelus. Dent Mater., 29: 580-93.

4. Dincol M, Ozbas H, Yilmaz B, Ersev H, Gokyay S and Olgac V (2016): Effect of the plant-based hemostatic agent Ankaferd blood stopper on the biocompatibility of mineral trioxide aggregate. BMC Oral Health,16: 11120.

5. Dreger LA, Felippe WT, Reyes-Carmona JF, Felippe GS, Bortoluzzi EA and Felippe CS (2012): Mineral trioxide aggregate and 
EVALUATION OF TISSUE RESPONSE OF ADULT MALE SPRAGUE-DAWLEY... ${ }^{15}$

Portland cement promote biomineralization in vivo. JOE, 38(3):324-9.

6. Gandolfi MG, Taddei P, Siboni F, Modena E, Stefano ED, Prati C (2011): Biomimetic remineralization of human dentin using promising innovative calcium-silicate hybrid "smart" materials. Dent Mater., 27: 1055-1069.

7. Guerreiro-Tanomaru JM, Vazquez-Garcia A, Bosso-Martelo R, Bernardi MI, Faria G and Tanomaru-Filho (2016): Effect of addition of nano-hydroxyapatite on physicochemical and antibiofilm properties of calcium silicate cements. J Appl Oral Sci; 24(3):204-10.

8. Hosseinzade M, Soflou RK, Valian A and Nojehdehian H (2016): Physicochemical properties of MTA, CEM, hydroxyapatite and nano-hydroxyapatite- chitosan cements. BioMed Resear- India, 27(2): 442-8.

9. Hwang Y, Hwang I, Kim M and Son H (2009): chemical composition, radiopacity, and biocompatibility of Portland cement with bismuth oxide. Oral Surg Oral Med Oral Pathol Radiol Endod.,107: 96-102.

10. Jefferies S (2014): Bioactive and biomimetic restorative materials: a comprehensive review part I. J Esthet Restor Dent., 26(1):14-26.

11. Malkondu O, Kazandag MK and Kazazoglu E (2014): A review on biodentin, a contemporary dentin replacement and repair material. BioMed Resear Inter., 1-8.

12. Minotti PG, Ordinola-Zapata R, Midena RZ, Marciano MA, Cavenago BC, Bramante CM, Garcia RB, Duarte MA and Moraes IV (2015): Rat subcutaneous tissue response to calcium silicate containing different arsenic concentrations. J Appl Oral Sci., 23(1): 42-8.

13. No Y, Li J and Zreiqat $H$ (2017): Doped calcium silicate ceramics: a new class of candidates for synthetic bone substitutes. Mater, 10:153-90.

14. Nygern H, Chaudhry $M$, Gustafsson $S$, Kjeller G, Malmherg $P$ and Johansson $K$ (2014): Increase of compact bone thickness in rat tibia after implanting $\mathrm{MgO}$ into the bone marrow cavity. J Funct Biomater.,5: 158-66.
15. Opacic-Galic V, Petrovic V, Jokanovic V and Zivkovic (2017): Histological evaluation of tissue reactions to newly synthetized calcium silicate and hydroxyapatite based bioactive materials: In-vivo study. Srp Arh Celok Lek., 145(7-8):370-7.

16. Rammelt S, Schulze E, Bernhart R, Hanisch U, Scharnweber D, Worch H, Hans Z and Biewener A (2004): Coating of the titanium implants with type I collagen. J Ortho Res.,1025-34.

17. Saghiri M, Orangi J, Asatouran A, Gutmann J, Garcia-Godoy F, Lotfi $M$ and Sheibani N (2017): Calcium silicate based cements and functional impacts of various constituents. Dent Mater J., 36(1): 8-18.

18. Saghiri M, Orangi J, Tanideh N, Asatourian A, Janghorhan K, Garcia-Godoy $\mathbf{F}$ and Sheibani (2015): Repair of bone defect by nano-modified white mineral trioxide aggregates in rabbit: a histopathological study. Med Oral Patol Oral Cir Bucal, 20(5): 525-31.

19. Saghiri MA, Tanideh N, Garcia-Godoy F, Lotfi M, Karamifar $K$ and Amanat D (2013): Subcutaneous connective tissue reactions to various endodontic biomaterials: An animal study. J Dent Res Dent Clin Dent Prospects, 7(1): 15-21.

20. Silva LG, Kim SH, Luczyszyn SM, Giovanini A and Almeida LE (2015): Histological and immunohistochemical evaluation of biphasic calcium phosphate and a mineral trioxide aggregate for bone healing in rat clavaria. Inter J Oral Maxilofacial Surg., 44(4): 1-26.

21. Silva Neto DJ, Schnaider TB, Gragnani A, Paulo de Paiva A, Novo NF and Ferreira LM (2012): Portland cement with additives in the repair of furcation perforations in dogs. Acta Cir Bras., 27(11):809-14.

22. Sonarkar S and Purba R (2015): Bioactive materials in conservative dentistry. Int $\mathbf{J}$ Contemp Dent Med Rev., 1-4.

23. Suzuki Y, Hayashi M, Tanabe N, Yasukawa T, HiranoY, Takagi S, Chow L, Suzuki N and Ogiso B (2015): Effect of novel 
fluorapatite-forming calcium phosphate cement with calcium silicate on osteoblasts in comparison with mineral trioxide aggregate. $\mathrm{J}$ Oral Sci., 1:25-30

24. Tanomaru-Filho M, Gracia AC, BossoMartelo R, Berbert FL, Reis JM and Guerreiro-Tanmaru JM (2015): Influence of addition of calcium oxide on physicochemical properties of Portland cement with zirconium or niobium oxide. J Conserv Dent., 18(2): 105108.

25. Tenorio de Franca TR, Silva RJ, Queiroz MS and Aguiar CM (2010): Arsenic content in Portland cement. A literature review. Indian J Dent. Res., 21 (4) 591-595.

26. Tschoppe $\mathbf{P}$, Zandim DL, Martus $P$ and Kielbassa AM (2011): Enamel and dentin remineralization by nanohydroxyapatite tooth pastes. J Dent., 39: 430-7.
27. Vosoughhosseini S, Mehrdad L, Moradzadeh M, Aghbali A, Rahimi S, Saghiri M, Zand V, Mehdipour M, Ranjkesh B and Doosti S (2012): Comparison of two histopathologic methods for evaluating subcutaneous reaction to mineral trioxide aggregate; Med Oral Patol Cir Bucal, 17(1): 41-4.

28. Yoshino P, Nishiyama CK, Modena KC, Santos CF and Sipert CR (2013): In vitro cytotoxicity of white MTA, MTA Fillapex and Portland cement on human periodontal ligament fibroblasts. Braz Dent J., 24 (2):1116. 


\section{تقييم استجابة الأنسجة لأسمنت كالسيوم سليكات تجريبى فى مقابل

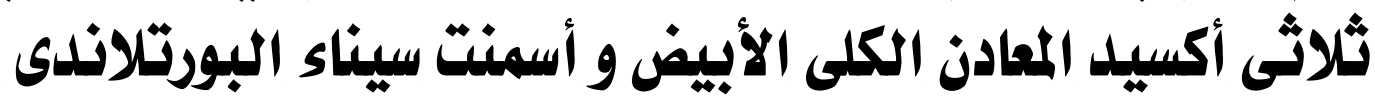 الأبيض}

أميرة محمد سامى مصطقى 1، محمد على اليسقى²، مها أحمد نيازى 3، محمد يسرى حسان4 1 قسم العلاج التحفظىـ كلية طب الأسنان -جامعة سيناء.

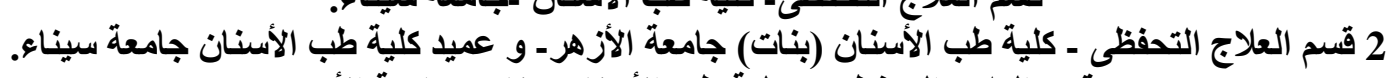

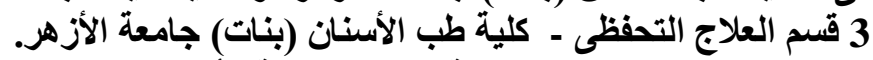

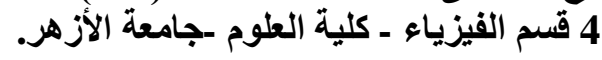

خلقية البحث: أسمنت كالسيوم سليكات مادة ذات تقبل حيوى و تساعد فى ترميم العظام.

الههف من الدراسة: أجريت هذه الدر اسة لتقييم و مقارنة إستجابة أنسجة جرذان التجارب لمادة معملية تجريبية فى مقابل ثلاثى أكسيد المعادن الكلى الأبيض و الاسمنت البورتلاندى الأبيض .

مواد و طرق البحث: تم تحضير المادة المعملية من الأكاسيد النظيفة. تم عمل فجوات فى قصبة سـاق الجرذ، و غرس مختلف المـو اد بهـا مـع ترك مجموعـة تحكم على حسـب الفتر ات المحددة لإجـراء الإختبار ات ومختلف المو اد المستخدمة فى كل مجمو عة عدا مجمو عة التحكم .

النتائج: أسفرت نتائج هذه الدر اسة عن زيادة الخلايا الالتهابيـة فى كل مجموعات الدر اسـة بعد مرور يوم واحد على الإختبار، وقد إنخفضت بعد مرور شـر من إجراء الإختبار ات، كما أظهرت نتائج الإختبار ات تكوينات عظمية جديدة تزيد بزيادة الوقت المقرر لاجر اء الاختبار ات.

الإستتناج: المادة المحضرة معمليا تثابه فى تأثير ها المو اد الحيوية التجارية.

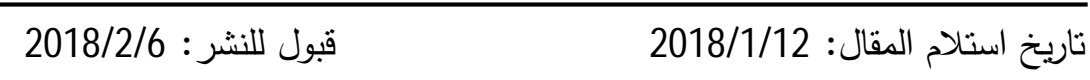

